\title{
SWOT Analyses of Mapping Activities at the Ministry of Defence Zrínyi Mapping and Communication Servicing Non-Profit Limited Company
}

\author{
KULCSÁR Gábor ${ }^{1}$
}

\begin{abstract}
The Ministry of Defence (MoD) Zrinyi Mapping and Communication Non-profit Lim- ited Company (Ltd) belonging to the Ministry of Defence was founded $1^{\text {st }}$ January

2013, by uniting the MoD Zrinyi Communication and MoD Mapping Non-profit Lim-ited Company. In order to ensure the most economical operation, the primary aim of the integration defined by the founder was the revision and possible merger of the ca-pabilities existing in parallel in the two companies. The two predecessor firms would now work as one company, preserving all capabilities, on separate premises, as sep-arate branches perform the mapping and communication tasks within the company. The mapping tasks, given their nature, cannot be accomplished market and profit based, therefore state funding is necessary. The support rate needed for the opera- tion changes from year to year and often during the year, which makes the planning of mapping task procedures rather difficult and as a result the fulfilment of tasks is less efficient.

The Ltd basically fulfils state tasks, however, in its spare capacity, business activities are also carried out. These business activities partly provide coverage for public tasks performed by the company, with which the amount of state funding can be lessened. The aim of my research was to examine the significant factors and effects determining the company's mapping activity and to elaborate the suggestions for the solution of the revealed problems through a Strengths, Weaknesses, Opportunities, Threats (SWOT) analyses.
\end{abstract}

Keywords: MoD Zrinyi Mapping and Communication Servicing Non-profit Limit- ed Company; mapping, SWOT

The basic function of the cartographic branch is to provide maps, geospatial databases, map- ping and printing products to the Ministry of Defence and to the Hungarian Defence Forces (HDF). Its further task is to produce and update the state topographic maps and cartographic databases, supply state and local government organizations, as well as the law enforcement and disaster recovery organizations, and to provide cartographic products to civil users.

The above mentioned tasks cannot be performed market and profit based, considering the fact that the tasks are, first of all, the mapping of areas belonging to the interest of Hungary, the HDF, and the obligations set up by international organisations. Secondly, tasks include the continuous maintenance of the cartographic data and databases of these areas. Financing of such tasks in general is a state responsibility in every country, therefore they are financed from the state budget.

1 MoD Zrínyi Mapping and Communication Servicing Non-profit Limited Company, Financial and Accounting Department 
In Hungary the user demands for the amount of the above mentioned tasks continuously reach the available full capacity of the company.

Table 1. Media Gateway Control Protocol (MGCP) Cells Fulfilment. (Source: author)

\begin{tabular}{|l|c|c|c|c|}
\hline \multirow{2}{*}{ MGCP } & \multicolumn{2}{|c|}{$\begin{array}{c}\text { The demand of the HDF } \\
\text { Geoinformation Service (GEOS) }\end{array}$} & \multicolumn{2}{|c|}{ Fulfilment } \\
\cline { 2 - 5 } & $\begin{array}{c}\text { Planned: } \\
\text { Finish Cells }\end{array}$ & $\begin{array}{c}\text { Planned: } \\
\text { Cells to proceed }\end{array}$ & Finished & To proceed at Q3 \\
\hline 2013 & 4 & & 4 & \\
\hline 2014 & 3 & 2 & 5 & \\
\hline 2015 & 4 & & 2 & 1 \\
\hline
\end{tabular}

At the same time, capacity expansion is not possible due to current financing. Indeed, there is an occasional temporary decrease in the capacity of certain professional fields, be- cause the extent of financing is different in each year and cannot be planned for a longer peri- od than a year. In the past six-eight years, the degree of pre-planned state financing decreased during the year, too. The temporary capacity reduction is by necessity in case of financing decrease, while in other cases it is due to the rather low wages of employees.

The reason for professionals leaving the company in most cases is the insecurity caused by the almost continuous reorganizations, the undervaluation of the cartographic field, the lack of moral and financial appreciation within the MoD and HDF.

Table 2. Average operational wages. (Source: [1] and author)

\begin{tabular}{|c|c|c|}
\hline Average operational wages & $\begin{array}{c}\text { Hungarian Central } \\
\text { Statistical Office } \\
\text { (HCSO - KSH) }\end{array}$ & MoD Zrínyi \\
\hline White collar worker & 384506 HUF & 288919 HUF \\
\hline
\end{tabular}

Professional workforce replacement on the cartography field (surveyors, photogram me- ter, geospatial expert, etc.) and on the map printing field (typographer, printing machine operator) is only possible by the employment of young career starters due to the low wages. After acquiring four-five years of experience at MoD Zrínyi Mapping and Communication Non-profit Limited Company, a part of these professionals decide to work abroad or in the business sector. Training the replacement workforce again, demands significant resource and expenses.

In the past twenty years, almost all of the current managers from the state sector of civil cartography have been able to name army cartography as their first, starter workplace. In the business sector the number of professionals in manager roles who were set off by the Ltd is of course also significant. In the past few years, despite the company's intentions, it has increased the number of well-trained surveyors and geographical information system (GIS) experts working abroad. The company cannot compete with the foreign wages, benefits and working environment in the above mentioned three fields. 
As a result of the annually changing financing, capacity reservation and supply of basic functions, certain professional fields of the company change every year. Due to the large number of basic functional tasks (and lack of financing), the capacity of the digital cartog- raphy field, sustained by state funding, is continuous, completely utilized. At the surveyor field, due to the periodic workflow (surveying tasks can only be performed in fair weather conditions, about 120 days per year) some tasks can only be done by working overtime. However, the capacity of the duplicator (printing office) field - because of the specificities of cartography techniques, annual financing and plannability - is only completely utilised in the last quarter of the year. In these periods overwork is also common.

The Ltd also performs business activities in order to utilize its spare capacities allowed by the MoD, support its basic functional tasks and to satisfy the civil map users' demands.

In the surveyor field, business activities can basically only be carried out in overtime work. In case of more timeconsuming tasks, missing capacity can be complemented by applying subcontractors. Staff increase is not advisable, since business activities can only be performed periodically and rhapsodically in time due to the economic environment. Work supply and financing of the increased staff for business activities cannot be solved.

Table 3. SWOT analyses of surveyor field. (Source: author)

\begin{tabular}{|c|c|}
\hline Strengths & Weaknesses \\
\hline $\begin{array}{l}\text { - wide variety of technical equipment } \\
\text { - professionals }\end{array}$ & $\begin{array}{l}\text { - } \text { prestige of employees } \\
\text { - labour migration }\end{array}$ \\
\hline Opportunities & Threats \\
\hline - state orders & - periodic workflow \\
\hline
\end{tabular}

Due to the continuous utilization of the full capacity of the digital cartographic field as well as to the labour safety rules, performing direct business activities is difficult in this spe- cial field. Staff increase for business activities on this field is advisable, but the Hungarian market is too small, however, there would be possibilities for international projects as well, as the company has the human and technical ability to accomplish international projects. The product of the field, different mutations of digital cartographic databases can be provided and sold according to the related laws and regulations. [2] The new law [3] could provide the state organisations (e.g. Healthcare, Police, Fire brigade, Disaster management) free access to the state databases.

Table 4. SWOT analyses of digital cartographic field. (Source: author)

\begin{tabular}{|l|l|}
\hline Strengths & Weaknesses \\
\hline $\begin{array}{l}\text { - state of the art technologies } \\
\text { professionals }\end{array}$ & $\begin{array}{l}\text { - labour migration } \\
\text { - interoperability with other companies } \\
\end{array}$ \\
\hline Opportunities & Threats \\
\hline state orders & lack of business activities \\
\hline
\end{tabular}


The utilization of the printing field capacity, regarding state orders, lags behind the fea- sible. Despite the Ltd's intension, requests, and the existing MoD instructions, a substantial part of MoD and HDF organizations still use civil printing houses instead of using the com- pany's spare capacities. By moving all the printing demand of MoD and HDF to the Ltd's printing house, the full capacity could be engaged by state orders. Plenty of MoD and HDF placards, publications, office products are printed in private printing houses, whereas the company's printing house has to seek for works from the civil market and perform business activities in order to survive. The Ltd has to pay the maintenance costs during spare capaci- ties as well, which generate higher printing costs.

Table 5. SWOT analyses of printing field. (Source: author)

\begin{tabular}{|l|l|}
\hline Strengths & Weaknesses \\
\hline $\begin{array}{l}\text { - wide variety of technical equipment } \\
\text { - professionals }\end{array}$ & $\begin{array}{l}\text { - high maintenance costs } \\
\text { free capacity }\end{array}$ \\
\hline Opportunities & Threats \\
\hline state orders & - difficult public procures of employees \\
\hline
\end{tabular}

In case of MoD and HDF, having all the printing work done by the Ltd would result in significant savings, since on the one hand, it would engage the Ltd's spare capacities and on the other hand, with the reorganization of the necessary financial support, tax could be saved for MoD and HDF organizations (since the Ltd would not work in venture and profit oriented fields, it would not need to provide invoices). Currently, the return for profit margin of the printing orders from civil companies could be saved this way. The full printing capacity of the Ltd could be planned and as a result, the total activity from raw material procurement to the production and handover of finished product could be performed far more economically. Further significant savings could be achieved by printing the total number of copies for each printing product at the same time - for MoD and HDF - because the cost of each copy would be significantly reduced.

The Ltd is at a significant disadvantage on the business field compared to its competitors, which are private companies. The current economic environment is not favourable for state companies, which operate and employ staff by keeping every law and principle completely. A significant proportion of the competing private companies go to the border of legality by using the gaps in law, or, in a worst case scenario, they even overstep these borders in the market competition to gain economic advantage. The solution - efficient supervision and displacement of such companies - is yet to be seen, therefore in the case of the Ltd an almost immediate solution could be the engagement of full capacity by state orders.

The most significant disadvantage for carrying out business activities is the existing public procurement law, [4] which makes the acquisition of large-scale business almost impossible on the market. Obtaining small quantity orders is also difficult and slowly feasible because of overregulation and compliance with the related rules, however, it is not yet impossible. 
State companies are affected the most adversely during their business activities by the following:

- Acquisition of materials needed for business activity can happen with public procure- ment process. Acquisition of large-scale material for business activities, usually due to the short deadlines, is basically impossible. The opportunity of the efficient operation of business activity is further decreased by the fact that because of the public procure- ment obligation, the Ltd is only allowed to purchase raw material at a reduced price from the winner of the public procurement procedure, which is not possible in practice.

- Enabling open market procurement at a lower price than during the public procurement procedure would significantly facilitate the operation of successful business activity.

- The subcontractor can be involved in business activities according to the public pro- curement rules. However, in case of large-scale projects the client does not wait until the Ltd carries out the public procurement process and finds a subcontractor. Instead, the client finds a quickly available partner. Furthermore, the public procurement pro- cess does not enable the Ltd to apply an already known and tried subcontractor for the business activity, since it cannot influence the result of the process. At the same time, applying an unknown partner would mean significant financial and moral risk.

The solution would be to allow the free selection of the subcontractor in case of business activity, with the condition that the payable price for the applied subcontractor cannot be higher than the price of the undertaken work and then the related special through fare accept- ed by the professional chamber, besides the profitability of the work.

Taking economic risks during business activities is currently not in the interest of the managers of state companies, since if profit is made, it is obvious; if loss is made (which obviously happens in the business sector) because of reasons beyond their control, they are impeached. Impeachment also happens if the company otherwise operates profitably and the loss can be measured in pennies. One cannot - and for certain managers it is not worth it - start factually risky business activity with state money even if that money comes from previously successful business activity and it would produce significant result.

In case of public companies, the existing statutory regulation is working against the oper- ation of successful business activity, since according to the law, if the revenues from the busi- ness activity do not reach $10 \%$ of the company's total revenues, the company is exempt from the payment obligation of the corporate tax. However, $10 \%$ is a very low limit, it would be worth abolishing this rule in case of $100 \%$ state-own companies, or at least increase it to $50 \%$.

\section{Conclusion}

In conclusion, it can be stated that in case of the Ltd, in order to ensure successful operation, increasing the business activity is impractical, instead, utilization of the company's total ca- pacity with state orders would be effective. All the more, since there is sufficient demand for the services from MoD and HDF organizations, from state and local government institu- tions. Moving the existing demands to the Ltd would certainly solve the problem of capacity utilization, and at the same time it could be solved easier than reorganizing the economic environment. It is not negligible either that it would result in significant savings on a state level, since financing the Ltd's non-profit activity is cheaper than purchasing other compa- nies profit-based services. 
KULCSÁR Gábor: SWOT Analyses of Mapping Activities at the Ministry of Defence Zrínyi Mapping...

In order to increase the labour hoarding ability, it can be claimed that the above described facts cause serious damage to the MoD portfolio and to Hungary's budget. To conclude: a long term steady, secure, predictable working environment, predictable career, competitive salaries and last but not least bigger moral respect should be offered to the employees of this professional field in order to reduce their leaving and to reduce the expenses due to their leaving. During annual planning it would be advisable to structure the company's annual expenses not by tasks but rather by the types of expenses, in which wages would appear as permanent fix costs.

The result of the business activity can be used for public utility tasks, however, at the company neither the managers nor the employees are motivated in any ways to perform busi- ness activities. Profitability could be improved by motivating the employees with financial tools in order to ensure more effective work and more economical material and energy usage. I suggest introducing an interest system on every field where production or service activities are carried out, independent of whether it is business or basic function task.

\section{References}

[1] KÖZPONTI STATISZTIKAI HIVATAL: A szellemi foglalkozásúak havi bruttó átlagkeresete a nemzetgazdaságban. Budapest: KSH, 2015. www.ksh.hu/docs/hun/xstadat/xstadat_evkozi/e_qli009b.html (downloaded: 2606 2015)

[2] 63/1999. (VII. 21.) FVM-HM-PM együttes rendelet a földmérési és térképészeti állami alapadatok kezeléséröl, szolgáltatásáról és egyes igazgatási szolgáltatási dijakról. www.hirosgeo.hu/jogszabalyok.php (downloaded: 2606 2015)

[3] 2012. évi XLVI. törvény a földmérési és térképészeti tevékenységröl. Magyar Közlöny, 61 (2012), 9916-9934.

[4] 2011. évi CVIII. törvény a közbeszerzésekröl. Magyar Közlöny, 86 (2011), 25268-25356. 